\title{
The Welfare State
}

\section{Definition of the term 'Welfare State'}

What is included as part of the Welfare State

Basic principles of the Welfare State

\section{The future of the Welfare State}

This short chapter is designed to introduce the subject of the Welfare State as a complete concept before we discuss some of its individual elements education, health and social security - in further chapters. The origins and principles of the Welfare State will be discussed and the changing attitude of the parties and their policy makers to it will be traced.

\section{DEFINITION}

There is no agreed definition of the term 'welfare state', though we can say that the description became widely used in the early years of the twentieth century. We can also make a clear distinction between a situation where the state provides a wide variety of welfare provision and one where there is a systematic arrangement for providing universal welfare through the state. This distinction can be illustrated by referring to health care provision in Britain.

Before 1946 health care was either privately supplied, in which case individuals simply paid for their own health care, while others were offered a state-subsidised system of health insurance. Those who did not take advantage of the insurance scheme were left without such care unless they could rely on charity and on local authority hospitals. Hospitals and doctors would save lives without reference to ability to pay, but other forms of health care were reserved for the well off or the state insured. Britain was, therefore, a state which provided basic health care for all and a voluntary insurance system, but the system was not universal. After the establishment of the National Health Service in 1946, however, the state guaranteed to provide 
health care for all, on demand and according to need. At the same time everybody in work was required to contribute through National Insurance payments. The NHS was both universal and compulsorily funded. A small private health sector remained for those whom preferred to pay for care.

We could apply a similar analysis to other services such as housing, education and social security, to illustrate the difference between the Welfare State as such and what had gone before. For our purposes we can identify a number of features which define the Welfare State (see box).

\section{The Welfare State}

- Benefits are universal, supplied free according to people's needs. Nobody is excluded.

- Contributions are compulsory, at least by those who are in work.

- The state guarantees to maintain certain minimum standards of welfare services. This is to ensure that state-run services are not significantly inferior to those supplied by the private sector.

\section{WHAT IS INCLUDED}

The term welfare is not a precise one so that a Welfare State may contain a variety of different services. In Britain, where the system is broad based, there is a large number of services included in the term. These are:

- The provision of personal health services, including medical research. These are centrally organised.

- Public health provision such as protection from virulent diseases, mass inoculation, services for the unborn child and young infants, provided by local authorities.

- Social services at a local government level. These deal with such issues as protection of children, including orphans, family support, care of the elderly at home and support for single parents.

- Subsidised housing, again at local level. Rents were heavily subsidised and local authorities were responsible for housing all residents and maintaining the housing stock.

- Education (under the 1944 Education Act) was to provided free for all those between the ages of 5 and 15 (later raised to 16), and for those who reached a good educational standard at 16-18 years. Places on degree courses were available for a small proportion of the most able. Later, post16 education was made available for all, and the number of university places were greatly expanded.

- A comprehensive system of social security was established. There were a wide variety of benefits available to all according to need. These included 
maternity benefits for pregnant women and nursing mothers, sickness benefits to compensate those who lost wages through illness, unemployment benefit, housing benefit for the very poor, family income support, again for the poor, child benefits for all families with children up to 16 years, free school lunches and uniform grants, old age pensions, death grants for funeral expenses and widows' benefit. In other words, benefits for all kinds of need which may occur within a family.

\section{BASIC PRINCIPLES}

These are more difficult to establish than a clear definition. This is because different political movements in Britain after World War II, while agreeing to the establishment of the Welfare State, presented differing attitudes to welfare. Here we shall examine three political traditions: Liberalism, Conservatism and Democratic Socialism (i.e. Labour).

\section{Liberalism}

It was Liberal thinkers from the nineteenth and early twentieth centuries such as T.H. Green, L. Hobhouse and T. Hobson who had proposed the ideas that a civilised, modern state should provide some broad levels of welfare for its people. This tradition (known as 'New Liberalism') provided the philosophical grounding for early state welfare systems at the start of the twentieth century. It was politicians such as Joseph Chamberlain (mayor of Birmingham) and David Lloyd George (prime minister 1916-22) who introduced the first practical measures.

Their view was that individuals could only be truly free if they were provided with opportunities and relief from the worst excesses of deprivation. They believed that people have a moral obligation to contribute to the welfare of others and that this was best achieved through the state.

The synthesis of theory and action came to its height with the rise to prominence of William (later Lord) Beveridge in the 1940s. A civil servant and later Liberal peer, Beveridge produced a report on the future of social policy in Britain in 1942. This was forever after known as the 'Beveridge Report' and represents the origin of today's Welfare State. The Beveridge principles, which are also those of the modern Liberal movement, were as follows:

- A variety of social evils, including poverty, lack of education and unemployment represented limits to the freedom of those who suffered them.

- It follows that the state should intervene in order to reduce these evils and so enhance freedom. 
- All are entitled to a minimum standard of living.

- In order to ensure such a standard of living it is necessary that all members of society should contribute to a pool of welfare.

- That all are entitled to draw from this pool according to their need.

Liberals and the Liberal Democrat party itself have supported the principles of the Welfare State ever since Beveridge. They consider it a vital part of a modern, civilised society.

\section{Conservatism}

Between the 1950s and the 1970s traditional Conservative thinkers and politicians supported the Welfare State. Being a pragmatic movement, Conservatism has accepted that this kind of welfare has improved the condition of the people and has become a popular device for promoting the common good. Though they may have had suspicions that a compulsory system of welfare inhibits individualism, they have supported it as part of a popular consensus.

When a new brand of Conservatism - the new right - emerged in the 1970s and 1980s, led by Margaret Thatcher, attitudes to welfare changed markedly. The new right feared that a 'dependency culture' had grown up whereby people had become used to depending on the state and this had sapped their sense of individual enterprise. They therefore sought to reduce the role of the Welfare State in a number of ways, replacing it with private-sector provisions.

The first target was subsidised housing. Council properties were offered for sale, at a discount, to their tenants. By the end of the 1980s many thousands of former council tenants had become home owners. Most of the rest of the subsidised housing system was transferred to voluntary housing associations which are outside the control of the state. The social security system also came under attack. Various benefits, such as unemployment support, child benefits and the old age pension were steadily eroded. These benefits were seen as a deterrent to work and to private insurance schemes or pension schemes.

Though education and health systems remained largely intact, new right Conservatives made no secret of their preference for private services and people were encouraged to take out private health insurance and to send their children to private schools. Private pensions, health and education all received generous tax reliefs in a period when the public services were in decline. Nevertheless the Conservative party could not bring itself to dismantle the Welfare State and its principles survived the onslaught which took place between 1979 and 1997. 


\section{Labour}

Although the Welfare State was essentially developed by Liberals, its establishment was seen as the crowning glory of the post-war Labour government. It became a symbol of the British form of socialism and was staunchly defended. That is not to say that Labour governments always treated the Welfare State kindly. It was Labour which introduced and often increased charges for prescriptions, dental care and eye checks. The principle that welfare benefits should be free at the point of demand was thus eroded almost immediately by the party which had introduced it.

Although the Labour party, while in opposition, defended the Welfare State against Conservative reforms in the 1980s, it failed to maintain the real value of pensions while in office and did not increase the proportion of National Income spent on either health care or education.

The advent of New Labour in the 1990s under John Smith and Tony Blair changed the party's attitude to the Welfare State. Their new interest in individualism led them to suggest that it was indeed up to individuals to make provision for their own welfare if they could afford to. A number of key measures have been taken by Labour which have gone some way to eroding welfare provision. The most striking act was to introduce tuition fees for university students. At the same time a system of 'stakeholder pensions' was introduced - a private pension scheme sponsored by the state, but left to individuals to make their own provisions. It was clear from this that there is an intention to erode or remove the state pension from future generations.

Labour's loss of enthusiasm for the Welfare State should not, however, be exaggerated. Its principles are still intact and there were substantial increases in pensions, child benefit and family benefits in the early part of the twentyfirst century. Similarly large increases in expenditure on the National Health Service and on schools followed, demonstrating that a strong faith in public sector welfare provision remained in the Labour party.

\section{THE FUTURE OF THE WELFARE STATE}

None of the major parties will admit that there is a possibility of the main aspects of the Welfare State being dismantled; but its prospects do not appear to be rosy. A future Conservative government, especially under its new leader, Iain Duncan Smith, may well decide to replace state health or education provision with private-sector arrangements. They have a sense that the Welfare State is not appropriate for a modern, pluralist society as there is sufficient prosperity for people to be able to make private arrangements. Furthermore, 
many in the party believe the private sector will provide better, more efficient, services than the state can do.

The Liberal Democrats still support the Welfare State staunchly. However, they are unlikely to form a government in the foreseeable future and their political influence remains weak. The best they can hope for is to influence the devolved governments of Scotland and Wales so that welfare remains under state control.

Uncertainty surrounds the future attitude of the Labour party towards the welfare State. The ordinary members of the party are unlikely to allow the principle to die, but the parliamentary leadership is much less attached to the idea of the Welfare State and may wish to modify, if not abolish it. As we have seen above, pensions and education seem to be most at risk, it may be that private health may make inroads into state welfare provision. Some form of universal social security will always be necessary, but it is very possible that future Labour administrations will continue to chip away at the benefits system.

If any government were to allow individuals to 'opt out' of the system in the future the Beveridge principles will have died, since universal contribution is what defines the Welfare State.

\section{SAMPLE QUESTIONS}

1 Assess the extent to which the neo-liberal economic reforms of the 1980s and 1990s resulted in fundamental changes in the UK economy.

2 Assess the view that Gordon Brown is a cautious rather than a radical Chancellor of the Exchequer.

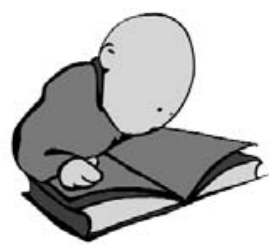

3 How much consensus on economic policy now exists in the British political system? 